\title{
The use of digital technologies in the administration of justice in the field of environmental crime
}

\author{
Natalia Kirsanova ${ }^{1}$, Valentina Gogoleva ${ }^{1}$, Tatiana Zyabkina ${ }^{1}$, and Kristina Semenova ${ }^{1}{ }^{*}$ \\ ${ }^{1}$ Peter the Great St. Petersburg Polytechnic University, 29, Polytechnicheskaya, Saint-Petersburg, \\ Russia
}

\begin{abstract}
In the present paper the authors consider technological and legal problems that arise in the course of adopting information technology in legal proceedings. The authors analyze the efficiency of using digital technologies in the administration of justice within the crisis period of 2020 on the basis of the World Justice Project, worked out by the Council of European Commission for the Efficiency of Justice CEPEJ. These technologies are used by both courts of the Russian Federation and courts of some other countries. The paper presents the analysis of prospects to apply artificial intelligence in the work of courts during adjudication on certain categories of disputes (issuance of a court order, consideration of cases as summary judgment proceedings). In order to ensure accessibility of justice, the authors urge on necessity to turn to online legal proceedings; they also highlight the necessity to organize special legal services for individuals (free-of-charge) and for business entities. The paper calls for the urgency to create a special digital portal for pretrial settlement of disputes between legal entities.
\end{abstract}

\section{Introduction}

Today creation of the information society is a priority task for the global community. The explosive growth in information technology and communications, their adoption in a variety of society spheres - economic, political, social, cultural, legal - confirm the inevitable digitalization of almost all aspects of human life, including the sphere of legal protection of violated rights and many other spheres [1-3]. The complication of socioeconomic relationships between entities results into an increase in pressure on the judicial system. In addition, despite the existence of a formal unconditional right to take legal actions, certain groups of entities cannot obtain justice in court for the reason that legal services are too expensive, or the procedure to file lawsuits is too complicated. According to the World Justice Project, an estimated 5 billion people have unmet justice needs globally [4]. The problem is aggravated by new technogenic and environmental challenges and threats, in particular the outbreak of COVID-19 that was declared a pandemic in 2020. The introduced quarantine restrictions in most countries caused the judicial lockdown,

\footnotetext{
*Corresponding author: semenova86@bk.ru
} 
when the activity of courts was totally paralyzed. For instance, by the Royal Decree, the Belgium courts were closed, limitation periods for expiring cases and for starting lawsuits were extended; in Spain, in compliance with Royal Decree No. 463, legal proceedings were suspended, in-person court hearings were canceled, with the exception of the cases requiring urgent and immediate measures or decisions (to protect interests of minors, decisions related to placing people to mental hospitals, or to grant interim measures), legal deadlines were also suspended; in Italy, in compliance with Legislative Decrees No. $11 / 2020$ and No. 18/2020, all legal proceedings and in-person court hearings were suspended, with the exception of the urgent cases of the civil and criminal law, the electronic document management system was introduced in courts; the Netherlands also suspended hearings of almost all types of cases, except for urgent, all the courts are introducing videoconferencing technology [5]. Generally, as the legal proceedings were suspended, European courts have had the backlog of pending cases. This has led to limited access of individuals and businesses to justice, the inability to protect their violated rights and to obtain justice. Consequently, we can draw a conclusion that most European courts are not ready to work in emergency, and that the whole judicial system of the Old World is rather conservative, with the legal and judicial community being "technologically myopic". In his monograph "Online Courts and the Future of Justice" R. Susskind points out that the legal community definitely resists adopting the innovative technology of online courts. This resistance shows not only the denial of the uptake of information technologies in legal proceedings, but proves the commitment of the legal and judicial community to the values and procedures of the traditional court system, their belief in the best practice of administering justice "in physical courtrooms, in a time-test environment, in public and physical spaces, where everybody can experience face-to-face hearings", i.e. administration of justice is impossible without conducting a formal ceremony involved judges and all parties to proceedings. However, R. Susskind strongly agrees with the statement of Susan Acland-Hood, HM Courts \&Tribunals Service chief executive, that "our processes do not need to be as old as our principles" [6]. It is hard to oppose to this viewpoint, especially in the era of rapidly evolved information technology and artificial intelligence. Analysis of court system organization in the developed states reveals that the court systems are expensive, slow and sometimes unintelligible.

The effective solution to overcome such problems is to integrate the information technology and artificial intelligence into performance of courts, to transform court hearings into online courts, primarily by submitting substantial legal data and related documents to e-reception, namely remotely from anywhere in the world 24 hours a day without extra charges (e.g. postal or courier service fees), enabling stakeholders to obtain judicial orders in no time in the e-document form. The above-mentioned will ensure openness of the court system, improve the quality and provide access to justice; it will reduce significantly costs of court proceedings and the workload of the judiciary and courts.

The necessity to develop "online courts", to introduce innovative digital technologies into EU courts long before the crises of 2020 was highlighted in the papers of Gutierrez Zarza A. [7], Lupo G. [8], Lodder A.R., Thomas F. Gordon, [9], Bex F., Prakken, H., van Engers T. et al [10]. From M.A. Osipova's standpoint, the exclusion of corruption during the administration of justice, ensuring its openness, and consequently enhancing trust in court on behalf of individuals and business entities, can take place via integration of information technology into the judicial system, which allows obtaining information in the sphere of justice, and obtaining legal protection of one's rights in due time [11].To illustrate the efficiency of the advanced information technology adopted in legal proceedings, we will turn to statistics on the efficiency and quality of justice provided by the European Commission CEPEJ, and the experience of the Russian Federation on optimization and digitalization of the court service in the crisis of 2020. According to the surveys, conducted 
by the European Commission for the Efficiency of Justice in 2020, the leader for adoption and application of information technology in legal proceedings, electronic interaction between litigants, is the Russian Federation. The overall performance assessment index for the use of digital technologies by Russian courts during the pandemic restrictions amounts to 8.81 points, whereas in Germany this assessment index amounts 8.3 points, in France 5.19, Italy - 6.42, Switzerland - 5.55 [12]. Unlike most European countries, the work of Russian courts was not paralyzed during the pandemic. The main reason for this is that Russia had embarked on reforms of its judicial system long before the crisis broke out. The judicial reforms included adoption of information technology in legal proceedings, organization of internet resources for the electronic document management system (KAD), the electronic filing system "Moy arbitr" (My arbiter) - for arbitration courts, the state automated system "Pravosudie" (Justice) - for courts of general jurisdiction, online court hearings in the form of videoconferencing. In addition, the surveys show that the Russian Federation is highly ranked by the time of considering cases in courts. For instance, the average time limit of resolving civil and economic disputes in Russian courts is 50 days, compared to the average European time - 233 days. Moreover, Russian judicial system performance is economizing, e.g. court financing in Russia accounts for 20.6 euros per person, compared to the average European financing -40.79 euros per person. The amount of court fees for settling court disputes in Russian courts is 3.4 euros per person, compared to the European 7.67 euros [12]. Thus, the optimization of Russian judicial system, adoption of brand-new digital technologies in its work enable us to draw a conclusion that the adoption of information technology and artificial intelligence in legal proceedings within the optimization of court performance prove to be relevant to the current challenges.

\section{Materials and Methods}

In the course of the research the authors relied on the general scientific methods - analysis and synthesis, private law methods - legalistic, comparative legal, and also special statistical research method. The analysis of efficiency in the sphere of development and adoption of information technology in courts, in particular in the courts of the Russian Federation, revealed the problems and complexities not only in the performance of the judicial community and courts, but individuals seeking justice. Using the comparative legal method, the authors considered the court performance within COVID-19 restrictive measures, i.e. the Royal Decrees of Belgium and Spain, legislative acts of Italy, regulatory acts of the Netherlands. The efficiency of adopting brand-new information technology in legal proceedings was considered by the statistical research method, using data of the European Commission for the Efficiency of Justice CEPEJ and the experience of the Russian Federation in the crisis 2020. The paper took advantage of doctrinal provisions, regulatory legal acts, statistics, internet resources on the given problematics, both national and international.

\section{Results}

The efficiency of legal proceedings in the field of development and adoption of information technology has a number of problems and complexities.

We focus on the most urgent, from our viewpoint, issues. Assumingly, the problems can be divided into two big groups - general and specific.

General problems are the following:

1. Double document flow and double workload of courts. The problem is that currently court officials have to register, enter data, classify cases etc. both electronically and 
manually. The obvious solution to this problem is to eliminate paperwork in courts, simultaneously making e-documents more secure by developing special software to prevent data leakage, cyberattacks, fraudulent claims and judicial acts. When it comes to document management system, Russian judicial system also suffers the problem of manual classification of cases by categories and manual checks of whether the submitted documents comply with legal procedural requirements. This problem is caused by the risk to lose documents submitted to courts electronically, if their amounts increase dramatically. Due to this, the solution that can be regarded outstanding for administration of courts is the one provided in Singapore. Since 1997 Singapore has used the system of e-submission of documents to courts. The intelligent automation system checks if all submitted documents comply with the procedural legislation, forms an e-case, classifies a case, ensures case progressing in court without court staff, which reduces the time of considering the case and prevents the loss of documents. In addition, all stakeholders (members court, litigants) have immediate access to the e-case [13-15].

Apart from this, e-justice solves the problem of storing paper files in the archives of the court, and this also simplifies court data recording.

2. The first problem leads to the second - the problem of ensuring safe and clear access to an electronic case both by the litigants (individuals and legal entities) and by the judge and the court administration, the inadmissibility of information transfer to third parties. Hence, there follows the problem of identifying parties of the judicial process, both individuals and legal entities. The solution to this complex problem, in our opinion, consists, firstly, in raising legal awareness of court officials, establishing responsibility, in particular, of the court administration for disclosure of confidential information; secondly, it is necessary to introduce new online services for judges on interagency electronic document flow (Federal Tax Service, Federal Bailiff Service, registering authorities, Federal Migration Service, etc.). An obvious move in this direction is the introduction of an online service for judges in January 2021 on the basis of an agreement between the Judicial Department of the Supreme Court of the Russian Federation and the Federal Notary Chamber - the developed software "Portal for Judges of the Unified Information System of Notaries" [16].

3. It is obvious that the ongoing transformation of legal proceedings involves adoption of new information technologies, including artificial intelligence. The issue of determining the legal status of "artificial intelligence", the introduction of "artificial intelligence" into legal proceedings, in particular the possibility of trusting a machine to make decisions instead of a judge, is currently urgent and debatable [17], turning at times almost into a religious dispute. According to certain opinions, "artificial intelligence", devoid of internal prejudices, is unbiased and able to make an objective decision. Others are categorically against passing over the decision-making function of courts to "artificial intelligence" for ethical and moral reasons [18-21]. However, in our viewpoint, in this context we are not calling for replacing a person (judge) by a machine, but about the possibility of getting the result of this person's (judge's) work using a machine or the "artificial intelligence" technologies, saving the judicial staff and court administration from routine work, reducing the time of considering cases and court costs, which will make justice more accessible to individuals and legal entities. In this regard, in our opinion, it is necessary to refuse to hold in-person court hearings on a wide range of simple, standard categories of indisputable cases, and to "delegate" decision-making on them to a cognitive artificial intelligence without direct participation of a judge, including formation of court orders and decisions issued under a simplified procedure. The relevance of this concept is no longer in doubt, as evidenced by the adoption of the European Ethical Charter on the use of artificial intelligence in judicial and related systems [22]. At the level of the Russian national legislation, this concept is in accordance with the Federal Target Program "Development of 
the Judicial System of Russia for 2013-2020" which involves the creation of mobile justice, electronic justice, formation of electronic cases and electronic archives of courts [23], and with the Presidential Decree "On the Development of Artificial Intelligence in the Russian Federation", which involves development of normative regulation of interaction between artificial intelligence and humans, and also development of ethical and moral norms of such interaction $[24,25]$.

In addition to the general problems, specific problems in the use of the existing electronic services of legal proceedings are clearly identified.

1. Lack of opportunity to fill out forms of applications (statements of claim) for common situations (application for a court order, application for dissolution of marriage, etc.) on electronic legal portals (websites), including the State Automated System "Pravosudie" and "Moy Arbitr". Not all individuals have even elementary knowledge of jurisprudence, not everyone has a financial opportunity to apply for qualified legal assistance, and problems need to be solved. Therefore, placing forms for filling out standard applications (lawsuits) on court websites would make justice more accessible to individuals and legal entities. Such a service is available on the websites of the courts in Great Britain [26].

2. Currently, there are a huge number of legal advice websites on the Internet, where questions are answered by a robot. The quality of such consultations sometimes raises doubts, on different sites, you can get cardinally opposite answers to the same question. Illiterate consultations of lawyers of many law firms also undermine the trust in the ability to receive high-quality legal assistance. Free legal aid within the framework of the state system of free legal aid is possible only for certain categories of citizens or in certain situations directly mentioned in the law. Websites of various ministries and departments Ministry of Internal Affairs, Federal Tax Service, regional and the Federal Notarial Chambers, etc. have their own services of "question-answer", "answers to frequently asked questions", etc. Along with that, in our opinion, in order to increase legal literacy of individuals and legal entities (not all companies have an in-house lawyer or financial opportunity to regularly apply for legal assistance or for legal support of their activities for qualified legal assistance), to make justice accessible, including financially, to strengthen trust and respect for the law, we should consider the possibility of placing free online legal assistance services on the official portals "State Services" on typical, most frequently encountered legal issues.

\section{Discussion}

However, despite the significant breakthrough in the digitalization of the Russian judicial system and gradual understanding of the need to use information technology in legal proceedings by the EU countries [24], analyzing the judicial systems of various countries in 2020 leads to the conclusion that in the framework of the rapidly developing information and digital space, one should not stop at the results achieved, even if they are very positive.

To achieve the goals of accessibility, transparency, openness, and simplification of justice, it is necessary to implement all new technologies, as well as to identify and eliminate conflicts and gaps in the legislation establishing the rules for applying information and digital technologies in order to improve the effectiveness of the judicial system [27-29]. It should be noted that the positive effect of the use of "e-justice" in the Middle East, in Iraq in particular, was noted in the monograph by Ahmed R.K., Mohammed K.H., Pappel I., Draheim D. "Impact of e-court systems implementation: a case study" [30].

We consider it necessary to note that understanding of the necessity of digitalization in the judicial system emerged after the digitalization of public administration and providing 
various public services via any electronic devices on accessible and comprehensible digital platforms [31-35].

\section{Conclusion}

Nowadays, in the conditions of dynamically developing information technologies and public relations, it is difficult to imagine a lawyer's work, including in-house, without IT tools: digital systems for information processing, standard contract constructors, intelligent platforms that analyze business risks, etc. The dynamics of the automation of legal processes, both existing and planned, can be visualized using the data given in the table (Table 1) [26].

Table 1. Automation of legal processes.

\begin{tabular}{|l|l|l|l|}
\hline & $\begin{array}{l}\text { Processes of automating legal } \\
\text { services in Russia }\end{array}$ & Automated (\%) & \multicolumn{1}{c|}{$\begin{array}{c}\text { Planned to } \\
\text { automate (\%) }\end{array}$} \\
\hline 1 & Contract work & 38 & 24 \\
\hline 2 & Legal knowledge base & 25 & 22 \\
\hline 3 & $\begin{array}{l}\text { Approval and issuance of powers } \\
\text { of attorney }\end{array}$ & 24 & 23 \\
\hline 4 & Claim-related work approval of & 20 & 26 \\
\hline 5 & $\begin{array}{l}\text { Development and } \\
\text { local acts }\end{array}$ & 10 & 9 \\
\hline 6 & Property management & 10 & 11 \\
\hline 7 & Legal support of labor relations \\
\hline 8 & $\begin{array}{l}\text { Accounting of trademarks and } \\
\text { patents }\end{array}$ & 5 & 8 \\
\hline 9 & $\begin{array}{l}\text { Interaction with supervisory } \\
\text { authorities }\end{array}$ & 4 & 8 \\
\hline 10 & Support of state control activities & 4 & 13 \\
\hline 11 & Legal support of licenses & 3 & 11 \\
\hline 12 & Legislative work & 1 & 6 \\
\hline
\end{tabular}

Intelligent automation systems that help lawyers reduce the share of routine work on the formation of model contracts, selection and analysis of judicial practice, claim-related work, portals of interaction with supervisory authorities, etc. can be afforded by large companies (Gazprom, banks). Similar portals to help businesses can also be established on the portal "State Services" for a modest fee.

In order to reduce the workload of arbitration courts, it is advisable to develop a digital service (on the website of an arbitration court or on the "State Services" website) to provide an opportunity of pretrial settlement of the simplest disputes between legal entities. An example is the Canadian project Cybersettle launched in 1996 [34]. Thus, the disputing parties send their claims and counteroffers to the online system. The system compares and analyzes the positions of the parties and, if the positions coincide, resolves the dispute automatically. If the parties (party) do not agree with the decision made by the system, it is possible to go to online negotiation. If the parties fail to reach an agreement, they have the right to move their dispute to court. As an incentive for litigants to resolve disputes amicably, we offer not to charge a fee for this service in case of an amicable agreement.

The scope of this paper does not allow us to analyze all the problems that arise, or that may arise in the future, through the use of information technology, both in the judicial system and in the lives of ordinary individuals and legal entities. However, as we assume, the ways of resolving the problems analyzed in this paper will help strengthen trust in the law, make justice accessible in all aspects, increase legal literacy of individuals and legal entities. 


\section{References}

1. A.I. Dashkina, A.M. Kobicheva, M.A. Odinokaya, D.A. Tarkhov, E3S Web Conf. 224, 03016 (2021) DOI: 10.1051/e3sconf/202124403016

2. T. Baranova, A. Kobicheva, E. Tokareva, Knowledge in the Information Society. PCSF 2020, CSIS 2020. Lecture Notes in Networks and Systems. Springer, Cham 184 (2021) https://doi.org/10.1007/978-3-030-65857-126

3. T. Baranova, A. Kobicheva, E. Tokareva, Digital Science 2019. DSIC 2019. Advances in Intelligent Systems and Computing. Springer, Cham 1114 (2020)

4. World Justice Project. Measuring the Justice Gap, https://worldjusticeproject.org/ourwork/research-and-data/access-justice/measuring-justice-gap

5. Russian Legal Information http://rapsinews.ru/incident_publication/20200413/305702705.html

Agency,

6. R. Susskind, Online Courts and the Future of Justice (Oxford University Press, 2019) https://doi.org/10.5817/MUJLT2020-2-9

7. Z.Á. Gutiérrez, Exchange of Information and Data Protection in Cross-border Criminal Proceedings in Europe. Springer (Berlin, Heidelberg, 2019) https://doi.org/10.1007/978-3-642-40291-3_16 2019

8. G. Lupo, Setting Foundations for the Creation of Public Value in Smart Cities. Public Administration and Information Technology, Springer, Cham 35 (2019) https://doi.org/10.1007/978-3-319-98953-2_4

9. A.R. Lodder, F. Thomas Gordon, Artificial Intelligence and Law 8, 255-264 (2000) https://doi.org/10.1023/A:1008327629468

10. F. Bex, H. Prakken, T. van Engers et al, Artif Intell Law 25, 1-3 (2017) https://doi.org/10.1007/s10506-017-9198-5

11. M. A. Osipova, Russian Journal of Criminology 3, 83-88 (2010)

12. European Commission for the Efficiency of Justice (CEPEJ) (2010) https://www.coe.int/en/web/cepej

13. Chan Sek Keong, 14th Conference of Chief Justices of Asia and the Pacific (Seoul, South Korea, 2011) http://app.supremecourt.gov.sg/data/doc/ManagePage/3841/CJ\%20Speech\%20at $\% 201$ 4th\%20Conference\%20of\%20CJs\%20of\%20Asia\%20and\%20the\%20Pacific.pdf

14. V.I. Reshetnyak, Russian Juridical Journal 2, 75 - 80 (2012)

15. J. Walker, D. Garry Watson, International and Comparative Law Review 31.1, 251294

https://digitalcommons.osgoode.yorku.ca/cgi/viewcontent.cgi?article=2378\& context $=\mathrm{S}$ cholarly_works

16. Judicial Department at the Supreme Court of the Russian Federation, http://www.cdep.ru/

17. N.B. Kirsanova, T.F. Zyabkina, K. A. Semenova, European juridical journal 10(149), 142-143 (2020) DOI: 10.46320/2073-4506-2020-10-149-142-143

18. I.N. Spitsin, I.N. Tarasov, Actual Problems of Russian Law 8, 96 - 107 (2020) DOI: 10.17803/1994-1471.2020.117.8.096-107 
19. V.B. Nagrodskaya, New technologies (blockchain/artificial intelligence) in the service of law: scientific training manual (Prospekt, Moscow, 2019) DOI: $10.31085 / 9785392284665-2019-128$

20. R.F. Zakirov, Herald of Civil Procedure 1, 211 - 219 (2018) DOI: 10.24031/22260781-2018-8-1-211-219

21. N.V. Antonova, S.B. Balkhaeva, Zh.A. Gaunova et al., Legal concept of robotization: monograph responsible (Prospekt, Moscow, 2019) DOI: 10.31085/97853923056502019-240

22. The CEPEJ European Ethical Charter on the use of artificial intelligence in judicial systems and their environment, https://rm.coe.int/ethical-charter-en-for-publication-4december-2018/16808f699c

23. Resolution of the Government of the Russian Federation No. 1406 of December 27, 2012, http://www.pravo.gov.ru

24. Presidential Decree of the Russian Federation No. 490 dated October 102019 , http://www.pravo.gov.ru

25. E. Dolzhenkova et al, IOP Conf. Ser.: Mater. Sci. Eng. 940, 012015 (2020)

26. Official website of HM Courts \& Tribunals Service - GOV. UK, https://www.gov.uk/govemment/organisations/hm-courts-and-tribunals-service

27. G. Lupo, The Case of Money Claim Online and Possession Claim Online in England and Wales, 111-160 (2013)

28. V.F. Borisova, S.F. Afanasiev, Ubiquitous Computing and the Internet of Things: Prerequisites for the Development of ICT. Studies in Computational Intelligence. Springer, Cham 826 (2019) https://doi.org/10.1007/978-3-030-13397-9_47

29. D. A. Tokarev, V. A. Usanova, N. Kagalnitskova, V.A. Sandalova, Ubiquitous Computing and the Internet of Things: Prerequisites for the Development of ICT. Studies in Computational Intelligence, Springer, Cham 826 (2019) https://doi.org/10.1007/978-3-030-13397-9_25

30. A. Završnik, Criminal justice, artificial intelligence systems, and human rights ERA Forum 20, 567-583 (2020) https://doi.org/10.1007/s12027-020-00602-0

31. R.K. Ahmed, K.H. Muhammed, I. Pappel, D. Draheim, Transforming Government: People, Process and Policy (2021) https://doi.org/10.1108/TG-01-2020-0008

32. O.V. Afanasieva, Public Administration Issues 3, 159-172 (2012)

33. M.Yu. Pavlyutenkova, Monitoring of Public Opinion: Economic and Social Changes Journal 5(153), 120-135 (2019)

34. V.N. Yuzhakov, Public Administration Issues 4, 243-254 (2020)

35. E. Dobrolyubova, E. Klochkova, O. Alexandrov, Digital Transformation and Global Society. DTGS 2019. Communications in Computer and Information Science, Springer, Cham 1038 (2019) https://doi.org/10.1007/978-3-030-37858-5_5

36. Cybersettle.com online in Canada, https://www. canadianunderwriter.ca/features/cybersettle-com-online-in-canada/ 